\title{
Milk consumption habits on dairy for farmers of family farming
}

\section{Hábito de consumo de leite por produtores de leite da agricultura familiar}

\author{
Daniela Andrighi ${ }^{1}$; Adriane Ferreira Frizzo ${ }^{1}$; Iucif Abrão Nascif Junior ${ }^{1}$; Karina Ramirez Starikoff ${ }^{1}$ (D) \\ ${ }^{1}$ Universidade Federal da Fronteira Sul, Fronteira Sul - SC, Brazil
}

\begin{abstract}
Brazil is one of the largest milk producers in the world and most establishments are small producers of family farming. Milk is a perishable product and due to its nutritional characteristics provides a favorable environment for the growth of bacteria. The objective of this research was to evaluate the consumption habits of milk in family farms, identifying the consumption forms, evaluating the risks and the perception of risk by the producers, besides evaluating the sanitary management adopted in the properties with respect to the diseases transmitted by the milk and milk products. One hundred eleven producers from the city of Realeza-PR were interviewed. Almost half $(48.64 \%, 54 / 111)$ had a small production with up to 10 lactating animals. Most of the producers had animals with a low productivity, and the average milk production per animal was less than 10 liters. The milk produced was consumed internally by $93.67 \%(104 / 111)$ of those interviewed, and 7.2\% (8/111) claim to ingest raw milk without any previous heat treatment. Some producers $(18 \%, 20 / 111)$ still made dairy products, like cheese and dulce de leche. Although $82.87 \%(92 / 111)$ reported having knowledge about the transmission of diseases through milk, only $49.54 \%(55 / 111)$ named the diseases. Not all producers conducted tests in the herd for disease control. The present study also found that only 4 people interviewed $(3.6 \%, 4 / 111)$ associated the consumption of raw milk with some illness and reported having some symptoms, such as vomiting, nausea, skin allergy, colic and gas. Thus, it is necessary to inform and guide producers about the risks associated with raw milk consumption, so that not only the health of the producer is assured, but also the family and the population that may acquire this product informally.
\end{abstract}

Keywords: Consumer behavior. Dairy. Raw milk. Questionnaire.

\section{RESUMO}

O Brasil está entre os maiores produtores de leite do mundo e a maioria dos estabelecimentos são de pequenos produtores da agricultura familiar. O leite é um produto perecível e devido as suas características nutricionais proporciona um ambiente favorável para o crescimento de bactérias. O objetivo desta pesquisa foi avaliar os hábitos de consumo de leite em propriedades da agricultura familiar, identificando as formas de consumo, avaliando os riscos e a percepção de risco pelos produtores, além de avaliar o manejo sanitário adotado nas propriedades com relação às doenças transmitidas pelo leite e derivados. Foram entrevistados 111 produtores do município de Realeza-PR. Das propriedades pesquisadas, quase metade $(48,64 \%, 54 / 111)$ tinham uma pequena produção com até 10 animais em lactação. A maioria dos produtores possuía animais com uma baixa produtividade, sendo que a produção média de leite por animal foi menor que 10 litros. O leite produzido era consumido internamente por 93,67\% (104/111) dos entrevistados e 7,2\% (8/111) afirmaram ingerir o leite cru sem qualquer tratamento térmico prévio. Alguns produtores $(18 \%, 20 / 111)$ ainda faziam derivados com o leite, como queijo e doce de leite. Apesar de 82,87\% (92/111) afirmarem ter conhecimento sobre a transmissão de doenças pelo produto, apenas 49,54\% (55/111) nomearam as doenças. Com relação a realização de exames, nem todos os produtores os realizavam. O presente trabalho ainda constatou que apenas 4 pessoas entrevistadas $(3,6 \%, 4 / 111)$ associaram o consumo de leite cru a algum mal estar e afirmaram apresentar alguns sintomas como, vômito, enjoo, alergia de pele, cólica e gases. Devido a isso, se faz necessário informar e orientar os produtores sobre os riscos associados ao consumo de leite, para que assim não só a saúde do produtor seja assegurada, mas da família e da população que pode adquirir este produto informalmente.

Palavras-chave: Comportamento de consumo. Lácteos. Leite cru. Questionário. 
Correspondence to:

Karina Ramirez Starikoff

Universidade Federal da Fronteira Sul

Campus Chapecó, Rodovia SC 484, Km 02

CEP: 89815-899, Fronteira Sul - SC, Brazil

e-mail: karina.starikoff@uffs.edu.br

Received: March 08, 2018

Approved: May 09, 2019

How to cite: Andrighi D, Frizzo AF, Nascif Junior IA, Starikoff KR. Milk consumption habits on dairy for farmers of family farming. Braz J Vet Res Anim Sci. 2019;56(2):e155455. https://doi.org/10.11606/issn.16784456.bjvras.2019.155455

\section{Introduction}

Brazil is the largest dairy producers in the world. Paraná stands out for its growth in production, with the Southwest region reaching the second largest dairy basin in the State (Brasil, 2016). The city of Realeza has about 770 milk producing properties, in which the majority use the family labor force. Family farming establishments represent $84.4 \%$ of all Brazilian establishments (Instituto Brasileiro de Geografia e Estatística, 2006).

The milk is a perishable product, is not naturally free of microorganisms, and also as one of the best resources provided for an environment favorable to the growth of bacteria (Menezes et al., 2014). Microorganisms may be from the animal, the milker or the environment, and may be excreted from the animal, or animal's skin and mucosa (International Dairy Federation, 1994). In Brazil, about $33 \%$ of the milk is produced informally, without going through any sanitary inspection (Sampedro et al., 2015).

Certain diseases can be transmitted by milk, called zoonoses, which can also contaminate food during the manufacturing processes of its derivatives, such as cheeses, yogurt, butter, curd, cream, among others, causing damage to health from whom to consume. These milk-borne diseases have great economic importance, as well as in public health, that in some cases the producer has the disease, but does not present the symptoms (International Dairy Federation, 1994).

The most well-known zoonoses are brucellosis and tuberculosis, which have a chronic character and interfere with the quality of life of the infected individual. Other microorganisms can be transmitted in milk and derivatives, such as: Listeria sp., Streptococcus sp., Bacillus cereus, Campylobacter jejuni, Staphylococcus aureus, which cause food poisoning (Vasconcellos \& Ito, 2011).
Procedures were created to reduce the levels of microorganisms present in milk, such as pasteurization, which aims to eliminate pathogens without altering the organoleptic characteristics of the product (Salvador et al., 2012). In addition, legislation mandating the inspection of products of animal origin helps with the goal of guaranteeing the quality of these foods and avoiding the occurrence of diseases (Brasil, 2017).

Thus, the objective of this research was to evaluate milk consumption habits in family farms, identifying the consumption patterns, assessing the risks and the perception of risk by the producers, as well as evaluating the sanitary management adopted in the properties with regard to the diseases transmitted by milk and milk products.

\section{Material and Methods}

This research was approved by the Committee of Ethics in Research under protocol 59783716.8.0000.5564 and was carried out by the application of a questionnaire to the milk producers of the family farming of Realeza city - PR, in the period between May and November 2017.

The participants answered a questionnaire composed of 19 questions, containing: name, location of property, age, gender, schooling level, family income, dairy activity (milking or feeding), how many people live with the producer, how many people in the family help in the activity and in what function. Questions about the consumption habits of milk, such as: consumption of milk or not and frequency of consumption; whether family members consumed milk; what was made with the milk, whether it was boiled or consumed raw; whether they made cheese or another derivatives; whether they used raw or boiled milk to make cheese; knowledge of the existence of diseases that can be transmitted by milk, someone in the family had some symptoms after drinking raw milk or its derivatives and what were its symptoms. Information about the property, such as: number of animals, average milk production per milking, existence of exams and vaccination for brucellosis and tuberculosis, if there was any disease in the herd and what was done with the animal.

For the income factor, seven income brackets were organized based on the prevailing minimum wage, and for the schooling factor, the fundamental, middle and higher levels, grouped in these three bands, were considered, even if the interviewed had or did not complete the level.

To analyze the results, the Microsoft Excel ${ }^{\circledR}$ program (2011) was used to verify the average and perform the percentages. The chi-square $(\mathrm{Q} 2)$ and odds ratio (OR) tests were also used to verify the association strength of 
the variables (Conti, 2009; Cerda et al., 2013). Regarding the statistical analyses made with the last two tests, the results on schooling, age, income and gender were used to verify the strength of association between these data and raw milk consumption by the interviewed.

\section{Results and Discussion}

One hundred eleven respondents participated: 96 men and 15 women. Regarding the age group, 33.3\% of respondents were 45 years old, $21.62 \%$ were between 46 and 50 years old, $44.14 \%$ had more than 50 years and one person did not answer this question (0.9\%).

About schooling: $73.86 \%$ attended until the fundamental level, and 57.65\% reported being incomplete; $21.61 \%$ interviewed did the average level and $4.5 \%$ did the higher level.

When asked about income, 36.03\% earned 1-2 minimum salary, $32.43 \%$ between $3-4,6.30 \%$ had low income less 1 , $13.51 \%$ between $5-6$ salary and $11.71 \%$ above seven times minimum salary.

About which function developed in the property, $8.10 \%$ did milking only, $16.21 \%$ fed the animals, while $63.06 \%$ did both activities and $12.61 \%$ did another work.

And about the production, $48.64 \%$ had a small production with up to 10 lactating animals at the time of the interview; $30.63 \%$ of the properties had between 10 and 20 lactating animals, $18.01 \%$ had between 20 and 30 animals and only $2.7 \%$ had more than 30 lactating animals.

The productivity of the animal (liters/cow/day), as can be observed in Figure 1, 38 producers to produce up to 40 liters of milk per day; 28 produced between 40 and 100 liters of milk, 23 produced between 100 and 300 liters of milk, 12 produced between 300 and 600 liters of milk and six produced more than 600 liters of milk per day, while four did not know the quantity of their milk production per day.

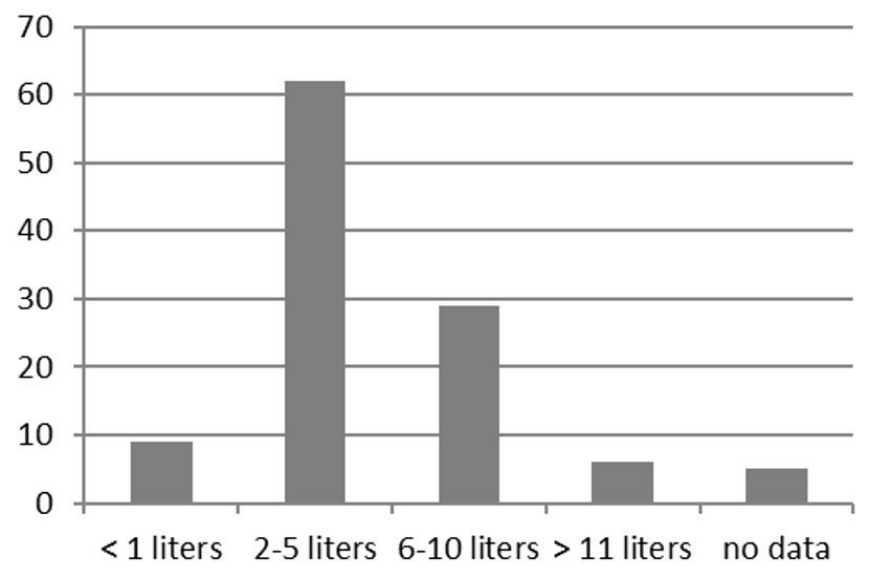

Figure 1 - Productivity of animals (liters/cow/day) of dairy farms in family farming. Realeza, Paraná, Brazil - 2017
Most of the producers that participated in this research (90.07\%) had animals with low productivity, with an average milk production per animal less than 20 liters. Following the results observed by the figure, it can be noted that more than 60 producers had animals with a productivity of 4 to 10 liters per animal per day, and less than 10 producers had animals that presented a production of more than 20 liters per animal per day. According to the Secretariat of State for Agriculture and Supply (SEAB), Brazilian cattle productivity, in the year 2014, was 1,525 liters of milk/cow/year, or 4.1 liters/cow/day (Brasil, 2016).

Comparing world productivity with Brazilian productivity, the country lost to France with a yield of 6,849 liters/cow/year, Germany with 7,541 liters/cow/year, United Kingdom with 8,131 liters/cow/year and also from the United States, which is the country with the highest dairy productivity, reaching 10,150 liters/cow/year. This shows that still needs to improve the herd by animal genetics, improving the conditions of the environment for the animal, as well as improving production systems, increasing the productivity of the herd (Zoccal, 2017).

The milk produced in the property is consumed by $93.67 \%$ of the producers, of these $76.57 \%$ do it daily, but $6.3 \%$ don't do it (Figure 2). The data found in this research was similar to those found in the study by Soares et al. (2010) in the state of Rio Grande do Norte, with 553 producers interviewed, and Nero et al. (2003) in the city of Campo Mourão, with 423 producers interviewed, where 92\% and $95.51 \%$, respectively, of respondents had a habit of consuming the milk produced. Still, in the Soares' research (2010), 511 of those interviewed who consumed milk, 84\% consumed it daily.

Few respondents lived alone (1.8\%), while $65.76 \%$ lived with 1 to 3 people and $32.43 \%$ with 4 to 5 people. And when questioned about the consumption of milk by the people who lived together: $84.68 \%$ said they consume, $7.2 \%$ did not consume and $8.1 \%$ did not answer this question.

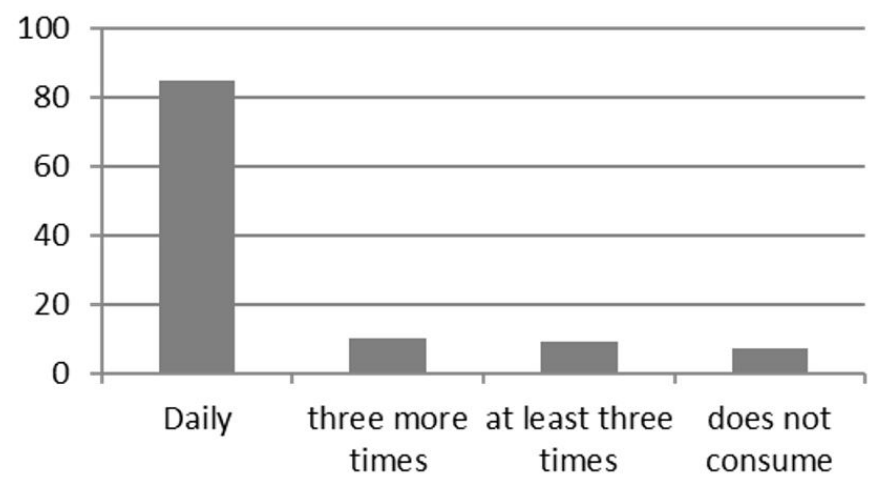

Figure 2 -Frequency of milk consumption in family farming. Realeza, Paraná, Brazil - 2017 
Before consuming the milk, $81.98 \%$ said they boil it, while $7.2 \%$ said they ingest the raw milk without any previous thermal treatment. In the research of Vidal-Martins et al. (2013). in the city of São José do Rio Preto/SP, with 805 respondents, $3.93 \%$ of the respondents answered that they consumed raw milk without boiling. Nero et al. (2003) found $33.57 \%$ of raw milk consumers in a city of Campo Mourão/PR.

The consumption of raw milk usually occurs due to lack of knowledge about the diseases that can be transmitted, as $73.86 \%$ had only completed elementary education. And through the results, $17.11 \%$ of the producers do not have this knowledge. In addition, the ingestion of raw milk can be due to the habits and tastes that the producers acquire by the product, ignoring the fact that it can transmit diseases.

About the derivatives, $18 \%$ of producers still make another product with milk, such as: dulce de leche, cream and curd. Nero et al. (2003) found that 40.14\% (57/142) of the consumers of raw milk produced milk derivatives, such as butter and dulce de leche. In this research, it was verified that $34.23 \%$ of the producers that made cheese did it with raw milk.

When questioned about the existence of diseases that can be transmitted by raw milk, $82.87 \%$ reported knowing about them, and among the most cited were brucellosis and tuberculosis. Still, 17.11\% do not know the existence of diseases that can be transmitted by milk, which reveals the lack of knowledge from part of the producers in relation to the risks that the product can bring to the health, besides, they don't know for sure which diseases can actually be transmitted by milk. Data found by Soares et al. (2010) show an even larger number $(92 \%, 511 / 553)$ of producers who are not aware of these diseases and their risks to public health.

Regarding tests in the herd, $86.49 \%$ of the producers responded for brucellosis, $72.07 \%$ for tuberculosis, $9 \%$ performed another test, but didn't know which disease and only $1.8 \%$ didn't take any tests. Brucellosis and tuberculosis testing, according to the National Program for the Control and Eradication of Brucellosis and Animal Tuberculosis (PNCEBT), is important to reduce the economic and social damages caused by these diseases, since they are two zoonoses relevant to public health (Brasil, 2017).

In addition, about $20.72 \%$ of the interviewed producers didn't perform any tests to detect mastitis, while $40.52 \%$ performed some tests ( 21 responded to CMT - California Mastitis Test, 9 performed using a mug test and 15 performed both tests). These are simple measures, cheap and quick and should be carried out before the start of milking. They contribute to the detection of clinical and subclinical mastitis, helping to ensure effective control of the disease in the herd (Empresa Brasileira de Pesquisa Agropecuária, 2008).

Mastitis affects the mammary gland of animals causing damage to the animal and to the producer. And it can cause food poisoning in humans, which results in impacts to the public health (Santos, 2012). There is unfamiliarity on the part of the producers regarding the food poisoning, and that can be caused by the same microorganisms responsible for mastitis. According to Santos (2012), the best way to prevent the occurrence of this disease, and consequently of intoxications, is to inspect the environment to which the animals are inserted, where there are a high number of pathogens.

In the statistical analyses performed, there was a small association between women and consumption of raw milk $(\mathrm{Q} 2=1.24$ and $\mathrm{OR}=2.6)$. This fact may have occurred due to the reduced number of women who answered the questionnaire; in addition, they spend more time cooking and preparing food, which may have favored the greater consumption of the raw product. Many producers consume raw milk because the product is "stronger", has more practicality and low cost (Nero et al., 2003). Also, milk is healthier, has no preservatives and is tastier (Vidal-Martins et al., 2013). Regarding the other variables, there was no significant association between them.

This study also found that $3.6 \%$ of the producers interviewed associated the consumption of raw milk with some illness and they presented some symptoms, such as vomiting, nausea, skin allergy, colic and gas. According to Delgado et al. (2010), a milk protein is one of the main causes of reactions. In Brazil, the incidence of people with lactose intolerance is $44.11 \%$, with children the main examples of that occurrence (Pereira \& Furlan, 2004).

\section{Conclusion}

Milk is among the most important products within Brazilian agribusiness. In addition, milk is a nutritional, complete, versatile product for human consumption. Milk is also a source that generates wealth for the agroindustry and for the small farmer who gets his sustenance from the production.

The consumption of raw milk and its derivatives, despite being small, is still practiced by producers of Realeza - PR. Much of this is the concept that the product is healthier and tastier, not taking into account as diseases that can be transmitted by this product. 
According to this research, there is no relationship between variables such as age, gender, schooling level with consumption of raw milk. In addition, most producers have knowledge about the diseases that can be transmitted by milk and conduct tests in the herd to keep it free of them.

\section{Conflict of Interest}

The authors state they have no conflicts of interest to declare.

\section{References}

Brasil. Secretaria de Estado da Agricultura e do Abastecimento. Leite: análise da conjuntura agropecuária [Internet]. Brasília: SEAB; 2016 [cited 2018 Feb 15]. Available from: http://www. agricultura.pr.gov.br/arquivos/File/deral/Prognosticos/2016/ bovinocultura_de_leite_2016.pdf

Brasil. Ministério da Agricultura, Pecuária e Abastecimento. Decreto n. 9.013, de 29 de março de 2017. Regulamento de inspeção industrial e sanitária de produtos de origem animal. Diário Oficial da União, Brasília (2017 mar. 30).

Cerda J, Vera C, Rada G. Odds ratio: aspectos teóricos y prácticos. Rev Med Chil. 2013;141(10):1329-35. http://dx.doi. org/10.4067/S0034-98872013001000014. PMid:24522363.

Conti F. Biometria: qui quadrado [Internet]. Belém: Laboratório de Infromática, UFPA; 2009 [cited 2018 Sept 14]. Available from: http://www.ufpa.br/dicas/biome/ biopdf/bioqui.pdf

Delgado AF, Cardoso AL, Zamberlan P. Nutrologia básica e avançada. 1. ed. São Paulo: Manole; 2010.

Empresa Brasileira de Pesquisa Agropecuária - EMBRAPA. Boas práticas de ordenha [Internet]. São Carlos: EMBRAPA; 2008 [cited 2018 Feb 8]. Available from: https://central3. to.gov.br/arquivo/228631/

Instituto Brasileiro de Geografia e Estatística - IBGE. Censo agropecuário: agricultura familiar. Rio de Janeiro: IBGE; 2006.

International Dairy Federation - IDF. The significance of pathogenic microorganisms in raw milk. Brussels: International Dairy Federation; 1994. 215 p.

Menezes MFC, Simioni CP, Etchepare MA, Huer-Ta K, Bortoluzzi DP, Menezes CR. Microbiota e conservação do

\section{Ethics Statement}

The protocol for the experimental study was approved by the ethics committee in research of the institution, number 59783716.8.0000.5564 (UFFS)

\section{Acknowledgements}

The authors thank ADAPAR - Agência de Defesa Agropecuária do Paraná, for helping in this research.

leite. REGET [Internet]. 2014 [cited 2018 Feb 15];18:76-89. Available from: https://periodicos.ufsm.br/reget/article/ viewFile/13033/pdf

Nero LA, Maziero D, Bezerra MMS. Hábitos alimentares do consumidor de leite cru de Campo Mourão - PR. Semin Ciênc Agrár. 2003;24(1):21-6. http://dx.doi.org/10.5433/1679$0359.2003 \mathrm{v} 24 \mathrm{n} 1 \mathrm{p} 21$.

Pereira D Fo, Furlan SA. Prevalência de intolerância à lactose em função da faixa etária e do sexo: experiência do laboratório Dona Francisca, Joinville (SC). Rev Salud Ambient. 2004;5(1):24-30.

Salvador FC, Burin AS, Frias AA, Oliveira FS, Faila N. Avaliação da qualidade microbiológica do leite pasteurizado comercializado em Apucarana-PR e região. Rev F@ pciência [Internet]. 2012 [cited 2016 Aug 14];9(5):30-41. Available from: http://www.fap.com.br/fapciencia/009/ edicao_2012/005.pdf

Sampedro GD, Silva MR, Faria LS, Souza GN. Fatores associados ao consumo informal de leite em pacientes com tuberculose na cidade de Juiz de Fora. In: Anais Eletrônicos do $15^{\circ}$ Workshop de Iniciação Científica da EMBRAPA Gado de Leite [Internet]; 2015; Juiz de Fora, MG. Juiz de Fora: EMBRAPA; 2015 [cited 2016 Aug 19]. Available from: http:// ainfo.cnptia.embrapa.br/digital/bitstream/item/142126/1/ Cnpgl-2015- RAnais-15Pibic-Fatores-leite.pdf

Santos MV. Mastite ambiental: efeitos no animal e no leite [Internet]. Inforleite (São Paulo). 2012 out; 48-50. [cited $2018 \mathrm{Feb} 8$ ]. Available from: http://qualileite.org/pdf/ Artigos-tecnicos-publicados-em-revista-de-divulgacao/ Inforleite/2012/3.pdf

Soares KM. P., Gois VA, Aroucha EMM, Verissimo AMOT, Silva JBA. Hábitos de consumo de leite em três municípios do Estado do Rio Grande do Norte. Rev Verde. 2010;5(3):160-4. 
Vasconcellos SA, Ito FH. Principais zoonoses transmitidas pelo leite. Rev mv\&z. 2011;9(1):32-7.

Vidal-Martins AMC, Bürger KP, Gonçalves ACS, Grisólio APR, Aguilar CEG, Rossi GAM. Avaliação do consumo de leite e produtos lácteos informais e do conhecimento da população sobre os seus agravos á saúde pública, em um município do Estado de São Paulo, Brasil. Bol Ind Anim. 2013;70(3):221-7. http://dx.doi.org/10.17523/bia.v70n3p221.

Zoccal R. Dez países top no leite [Internet]. Revista Balde Branco (Juiz de Fora). 2017 abr. 17 [cited 2018 Feb 25].
Available from: http://www.baldebranco.com.br/dezpaises-top-no-leite/

Financial Support: Author declares this study has been exempt of financial support.

Authors Contributions: Daniela Andrighi, Adriane Ferreira Frizzo, Iucif Abrão Nascif Junior and Karina Ramirez Starikoff participated in the writing of the article, considering the reading and review stages. 